\title{
An assessment of the perceived professional development needs of Turkish as a foreign language teachers
}

\author{
Nihan Aylin Ünlü a* (D), Hüseyin Öz ${ }^{\mathrm{b}}$ (i) \\ ${ }^{a}$ Hacettepe University, Ankara 06800, Turkey \\ ${ }^{b}$ Hacettepe University, Ankara 06800, Turkey
}

\section{APA Citation:}

Ünlü, N. A., \& Öz, H. (2019). An assessment of the perceived professional development needs of Turkish as a foreign language teachers. Journal of Language and Linguistic Studies, 15(2), 618-632.

Submission Date:08/03/2019

Acceptance Date:07/06/2019

\begin{abstract}
This study aimed to investigate the professional development needs of Turkish as a foreign language teachers and to examine whether there was a difference among the professional development needs of teachers with different educational backgrounds. To this end, the professional development needs of teachers were first investigated through a questionnaire administered to a total of 160 participants. Then, 15 teachers were interviewed in focus groups randomly selected from Turkish teaching centers (TÖMER) in Ankara. The population of the study was teachers working in Turkish language centers and institutes around Turkey. As a research method, the explanatory sequential mixed method was used. In the analysis of the data, descriptive and prescriptive statistical analyses were conducted and content analysis was used in the analysis of the interviews. Findings revealed that teachers needed to develop speaking and writing skills in both assessment and teaching. Professional development needs of the teachers varied according to age, occupational experience, the department they graduated from and the latest graduation degree. Finally, pedagogical implications of our research are briefly considered.
\end{abstract}

(C) 2019 JLLS and the Authors - Published by JLLS.

Keywords: Professional development; teaching Turkish as a foreign language; needs analysis

\section{Introduction}

The main purpose of any society wishing to gain an important place in the globalized world is to raise well-educated individuals. There are different stakeholders, such as teachers, students, managers, professional development specialists, families and society, to improve the quality of education provided to students during the schooling process (McLaughlin \& Talbert, 2006). However, the most important place in this process belongs to teachers who both implement the curriculum in the classroom and take the responsibility of student success. For this reason, the most basic element in the learning process is to train teachers at highest quality.

\footnotetext{
* Corresponding author. Tel.: +09-312 $2978092-93$

E-mail address: naylin@hacettepe.edu.tr

*This article is part of the first author's PhD dissertation "An Assessment of the Perceived Professional Development Needs of Turkish as a Foreign/Second Language Teachers" completed with the supervision of Assoc. Prof. Dr. Hüseyin Öz at Hacettepe University.
} 
Richards and Farrell (2005) argue that teachers need a constant education and development to sustain long-term success. According to Richards and Farrell (2005), "the field of language teaching is facing rapid changes. As a result, teachers need regular professional development opportunities to update their professional knowledge and skills" (p., vii). Wyatt (2016) also explains the interdisciplinary nature of teacher learning by stating, "teaching is a learning profession" (p. 3).

Given that professional development activities provide opportunities for teachers to develop their skills and add up new ones to the already present skills, professional development of teachers has recently become increasingly important around the world. Many studies show that professional development activities teachers participate in and outside the school positively influence their potentials as teachers (Desimone, Porter, Garet, Yoon, \& Birman, 2002; McLaughlin \& Talbert, 2006). However, how the professional development activities are organized is also a very important factor. Currently, in many parts of the world, the method usually applied in continuing professional development activities is to participate in independent workshops or presentations in which teachers are offered new ideas, knowledge and practical advice, but guidance on implementation is rarely provided (Guskey, 2000). In this way, teachers are expected to receive a new piece of knowledge and apply it in their classrooms. In this top-down approach, teacher is seen as the person who consumes the information because he or she is asked to apply the information determined by others without asking him whether he feels the need to be educated on this particular topic (Borg, 2015). Borg (2015) argues that a good continuing professional development process should:

- be relevant to the needs of teachers and students,

- involve teachers in decisions about content and process,

- support teacher co-operation,

- be supported by the school management,

- involve both exploratory and reflective thinking, taking into account both practices and beliefs,

- involve inclusion of internal and external support elements for teachers (e.g., experienced teachers support new teachers),

- follow contextual sequencing (in relation to the institutional, educational, social and cultural environment),

- consider the information received critically,

- value teachers' experiences and knowledge (p., 6).

Since the field of teaching Turkish as a foreign language does not have its own undergraduate program yet, education is provided by teachers who graduated from different departments such as Turkish Education, Turkish Language and Literature, Western Languages and Literatures, English / French / German Language Education, Linguistics. This situation leads to different professional development needs for teachers of Turkish as a foreign language. Therefore, professional development activities are required to be organized in line with the needs of teachers working in this area in order to involve teachers effectively in the process.

Over the past decade a number of master's and doctoral studies have been conducted on professional development needs and practices of foreign language teachers in Turkey (Çınkır, 2017; Karaaslan, 2003; King, 2015; Koçoğlu, 2006; Korkmazgil, 2015; Korkmaz, 2015; Muyan, 2013; Yağc1, 2014). However, there is no study about this subject in the field of teaching Turkish as a foreign language, which is a new field. Therefore, this study primarily aims to determine the needs of teachers working in the field of teaching Turkish as a foreign language and the differences in the needs of teachers in terms of age, experience, latest graduation degree and educational background. 


\subsection{Literature review}

\subsubsection{Teaching Turkish as a Foreign Language}

Turkish is the official language of the Republic of Turkey and it is the native language of more than 83 million people. Turkish is also spoken in other countries such as Germany, Australia, Belgium, Bulgaria, the Netherlands, the UK, Cyprus, Iraq, Syria, Romania, Macedonia, Kosovo and Greece by the Turkish people who live there. Approximately 200 million people speak Turkish all over the world. "Some of these languages are closely related to Turkic". (Bayraktaroğlu and Bayraktaroğlu, 1992, p.1). Turkish is seen as an important language due to historical reasons and its geographical, political and economic position in the world. Therefore, many universities in the world have Turcology departments, and the number of people who want to learn Turkish is increasing day by day.

Recently, a growing body of research about teaching Turkish as a foreign language has been done in Turkey. After 1950, teaching of Turkish as a foreign language at universities in Turkey began to increase. With the student project of the Turkish world, young people have been brought to Turkey by the Ministry of National Education to study in high schools and universities and to pursue a master's and doctorate degrees since 1991 (Göçer \& Moğul, 2011, p. 801). One of the objectives of this project was to teach modern Turkish language to Turkic Republics and the relative Turkish community youth and to promote Turkish culture and education system. It aimed to transfer Turkish language and culture to the new generations and disseminate modern Turkish language through this youth (Göçer \& Moğul, 2011, p. 801).

Since the Republican era, some universities have pioneered in teaching Turkish to foreigners. Turkish Teaching and Research Center (TÖMER), which was founded in 1984 by Ankara University to teach Turkish to foreigners, is one of the most important Turkish education institutions in Turkey. Ankara University TÖMER also published a series of Turkish language learning course book titled Yeni Hitit Turkish Education Series for Foreigners, which was developed to teach Turkish as a foreign language. In the following years, language-training centers (TÖMER, DİLMER, DEDAM, FÜSEM, HÜDİL etc.) were opened in the universities to teach Turkish as a foreign language. In many universities, postgraduate education programs for teaching Turkish as a foreign language have been launched.

Turkish Language Institute, Turkish International Cooperation and Development Agency (TIKA) and Yunus Emre Institute are also very important in the field of teaching Turkish to foreigners. Turkish language teaching series, Güneş-Türkçe Öğreniyoruz, were prepared by TIKKA for using in teaching Turkish to foreigners (Göçer, 2009, p.1301). Yunus Emre Institute prepared Yedi İklim Türkçe series for teaching Turkish to foreigners.

\subsubsection{Professional Development}

Professional development is understood and defined in different ways. Generally speaking, professional development means that someone develops in his or her professional role. In addition to formal experiences such as professional development seminars, conferences, professional meetings, and mentoring from more experienced teachers, there are informal experiences such as following publications in the field, participating in or following groups or watching television programs (Ganser, 2000). For this reason, the concept of professional development is broader than the progression of a teacher in the career cycle, and is broader than the development of the staff which aims at the group development of the teachers because it is only one of the systematic interventions that can be used for the professional development of teachers (Glatthorn, 1995, p. 41).

Traditional approaches and practices for teacher development usually involve teachers participating in in-service training and workshops where new ideas, information and practical suggestions are presented. The underlying assumption of traditional education is that teachers can take this information and then immediately apply it in their classroom. However, when examining the literature on teacher 
professionalism, it seems that there are some problems related to the effectiveness of in-service training, workshops and seminars carried out without considering the individual needs of teachers (Borg, 2015; Guskey, 2000; Lieberman \& Wilkins, 2006).

Traditional approaches are often criticized on the ground that the contents of the professional development activities are determined by others; these activities are prepared by taking the shortcomings of the teachers their basis and they are short-termed. Borg (2015) argues that these outsourced professional development practices can negatively affect teachers' wish to learn something new. Another disadvantage of this practice is that teachers may become dependent on the resources put forward by others instead of learning to take responsibility for their professional development. Another negative aspect of this practice is the possibility that teachers ignore their knowledge and experience, believing that what they learn from trainers in these seminars is more important. The most important problem is that continuous external professional development activities tend to limit the contributions teachers can make for content and process. Traditional continuing professional development approaches tend to take place in the training hall without considering the classroom environment, where teachers' professional lives are most prevalent, and without focusing on teacher beliefs and teacher behavior.

\subsubsection{Needs Analysis}

The need can be defined as the inconsistency between the present and desired situation, but it does not necessarily mean a desire. In other words, the need expresses the gap between what is present and what should be (Kaila, 2005, p. 128) Altschuld and Kumar (2010) emphasize that this incoherence or void must be measurable. In other words, when the "present situation" and the "necessary" situation are assessed, the difference between them determines the need.

Nunan (1998) defines needs analysis as the techniques and processes used to gather information to be used in curriculum design (p. 183). Brown (1995) defines need analysis as "the systematic collection and analysis of all subjective and objective information necessary to define and justify the defendable curricular objectives that meet the learning needs of students in the context of certain institutions which affect their learning and teaching situations" (p. 36). Richards and Schmidt (2010) consider needs analysis, as a component for the development of a language-training program and it is imperative that it is done before the curriculum development. All these needs analysis definitions emphasize collecting information in a specific context. In order to be able to make effective training programs, it is necessary for the participants of the programs to assess the need by collecting data in the context they are working.

\subsection{Research questions}

This research aims primarily to determine the needs of teachers working in the field of teaching Turkish as a foreign language and the differences in the needs of teachers in terms of age, experience, latest graduation degree and education. The present research is significant due to the lack of resources related to the professional development needs of Turkish as foreign language teachers in Turkey. In this study, the following research questions were addressed:

1. What are the professional development needs of Turkish as foreign language teachers?

2. Does the professional development needs of teachers who teach Turkish as a foreign language differ according to age, experience in the field, educational background and the latest graduation degree variables? 


\section{Method}

The present study employs a mixed-methods design in which both qualitative and quantitative research methods are used. Mixed-method design is the process of collecting, analyzing and "mixing" both quantitative and qualitative methods to understand a research problem (Creswell, 2012a, p. 535) The basic assumption in this sense is that quantitative and qualitative methods can be used together to provide a better understanding of the problem of research question than using the two methods separately. The model of the research is the Explanatory sequential design (QUANTITATIVE $\rightarrow$ qualitative) design. Quantitative data were collected first. Qualitative data were then used to support and expand the quantitative data.

\subsection{Participants}

The sample of the study was 160 randomly selected teachers of Turkish as a foreign language teaching at universities and institutes in various places in Turkey. $93(58.1 \%)$ of the participants were females and 67 (41.9\%) of the participants were males. The participants ranged in age from 22 to 50. In terms of experience, the majority of participants had experience of 1-10 years (90.6\%). Regarding the educational background $122(76.3 \%)$ of the participants graduated from Turkish Language and Literature and Turkish Education departments, while 38 (23.8\%) of the participants graduated from English/French Language Education, Linguistics and Western Languages and Literatures departments. Regarding the latest educational degree of the participants the majority of the participants had graduate degrees (67.6\%). Most of the participants (85.6\%) taught more than 15 hours per week. For the interviews 15 participants who accepted to participate in the study were selected.

\subsection{Instruments}

\subsubsection{Professional Development Needs Analysis Questionnaire}

The data were gathered by a questionnaire developed by the researcher to determine the demographic characteristics of Turkish as foreign language teachers in the research, as well as their professional development needs and perceptions, professional development practices and the reasons preventing them from participating in professional development activities. The measurement tool was prepared by analyzing the surveys related to the professional development used in previous studies (Arıkan, 2002, Ekşi, 2010, Gültekin, 2007, Karaarslan, 2003) and the TALIS (2013) survey prepared by the OECD. The questionnaire was designed in the 5-point Likert scale format and it consisted of five parts.

The validity of the questionnaire used in the study and the question form used in the interviews were verified by the assessment experts before the administration. The internal consistency of the scale was measured using Cronbach alpha and was $\alpha=.94$, which indicated that the scale was reliable to use in the study.

\subsubsection{Focus Group Interviews}

The qualitative part of the study was composed of focus group interviews. While the data collection tool was being developed, the field on teacher professional development was examined and the areas to be investigated in the light of the research questions of the study were determined. Prior to the consultations, expert opinion was sought regarding the validity and applicability of the interview questions.

\subsection{Data collection procedures}

In the current study data was first collected through the aforementioned questionnaire from the teachers working in Turkish teaching centers in different universities and institutes in Turkey. Before 
its implementation the questionnaire was piloted with 50 teachers and they did not report any problems in completing it. The researcher distributed the questionnaires to the participants in Ankara. For the participants living in other cities a Google online questionnaire form was prepared and sent out to their email addresses. Then, focus groups were formed with the teachers who agreed to participate in the study. In these focus groups, teachers' needs related to their professional development, their practices and the elements they considered to be obstacles to their participation were discussed. Voice recordings were made of these interviews, and then transcription was done and content analyses were conducted.

\subsection{Data analysis}

In order to analyze the data obtained from the questionnaire descriptive statistics was used. It was analyzed using the SPSS 22.0 (Statistical Package for Social Sciences) program. The perceptions and needs of the teachers participating in the survey were first described as percentage-frequency and crosstabulation, and then dependencies of needs to demographic variables were checked by chi-square analysis and the results were interpreted.

So as to analyze the data obtained from the Focus group interviews, which constitute the qualitative part of the study, content analysis was used. Content analysis can be defined as bringing together similar data within the framework of specific concepts and themes and interpreting them in a way that readers can understand (Yıldırım \& Simsek, 2008, p. 46). After reading the data the text was thematically coded using an inductive and interpretive approach (Creswell, 2012b). In order to increase reliability, to reduce bias and to make comparisons between categories, qualitative data were primarily written and read, followed by coding in a general framework and frequency calculations of words. Then, the codes that form an integral and meaningful whole are combined under themes. Two researchers separately analyzed the data to ensure the validity of interpretation.

\section{Results}

\subsection{Findings of Professional Development Needs Perceived by Teachers Teaching Turkish as a Foreign Language}

As can be seen in Table 1, with regards to the areas, in which Turkish as a foreign language teachers generally wanted to develop themselves most in teaching, writing and speaking skills of the students were recurrently mentioned skills. Pronunciation and reading were in the last place. The most important element in the teaching of skills that requires students to get involved in production, such as speaking and writing, was to enable learners to acquire communicative competence, not just learning words and putting them next to each other. For this reason, it was expected that participant teachers should feel more need to improve themselves in the teaching of these skills in teaching Turkish as a foreign language.

Table 1. Need for Development in Teaching

\begin{tabular}{lcccccccccc}
\hline & $\begin{array}{c}\text { I don't feel need at } \\
\text { all }\end{array}$ & \multicolumn{2}{c}{ I feel a little need } & \multicolumn{2}{c}{ I'm not sure } & \multicolumn{2}{c}{ I feel need } & \multicolumn{2}{c}{ I strongly feel } \\
& $\mathrm{n}$ & $\%$ & $\mathrm{n}$ & $\%$ & $\mathrm{n}$ & $\%$ & $\mathrm{n}$ & $\%$ & $\mathrm{n}$ & $\%$ \\
\hline Reed & 51.2 & 40 & 25 & 36 & 22.5 & 18 & 11.3 & 16 & 10 \\
Writing & 32 & 20 & 25 & 15.6 & 36 & 22.5 & 33 & 20.6 & 34 & 21.3 \\
Listening & 35 & 21.8 & 30 & 18.8 & 39 & 24.4 & 32 & 20 & 24 & 15 \\
Speaking & 37 & 23 & 33 & 20.6 & 26 & 16.3 & 34 & 21.3 & 30 & 18.8 \\
Grammar & 53 & 33.1 & 37 & 23.1 & 26 & 16.3 & 25 & 15.6 & 19 & 11.9
\end{tabular}




\begin{tabular}{lllllllllll} 
Vocabulary & 49 & 30.6 & 39 & 24.4 & 25 & 15.6 & 27 & 16.9 & 20 & 12.5 \\
Pronunciation & 57 & 35.5 & 38 & 23.8 & 22 & 13.8 & 20 & 12.5 & 23 & 14.4 \\
\hline
\end{tabular}

Table 2 shows that, regarding the areas in which Turkish as foreign language teachers generally want to develop themselves the most in terms of evaluation were writing and speaking and for evaluating grammar and vocabulary they felt the least need. Writing and speaking are among the skills, which develop the last for foreign language learners. The reason for this is that writing and speaking skills require using many skills together, such as comprehension, grammar skills and high-level thinking skills. When evaluating students' writing, they need to be clear about the intentions of teachers' evaluations. The rubrics provide both student and teacher convenience in the evaluation of these skills. The lack of such rubrics leads teachers to feel that they need to improve themselves in evaluating speaking and writing skills.

Table 2. Need for Development in Evaluation

\begin{tabular}{lccccccccccc}
\hline & \multicolumn{2}{c}{$\begin{array}{c}\text { I don't feel need } \\
\text { at all }\end{array}$} & \multicolumn{2}{c}{ I feel a little need } & \multicolumn{2}{c}{ I'm not sure } & \multicolumn{2}{c}{ I feel need } & \multicolumn{3}{c}{ I strongly feel } \\
& $\mathrm{n}$ & $\%$ & $\mathrm{n}$ & $\%$ & $\mathrm{n}$ & $\%$ & $\mathrm{n}$ & $\%$ & $\mathrm{n}$ & $\%$ \\
\hline Reading & 57 & 35.6 & 33 & 20.6 & 27 & 16.9 & 25 & 15.6 & 18 & 11.3 \\
Writing & 33 & 20.6 & 26 & 16.3 & 33 & 20.6 & 32 & 20 & 36 & 22.5 \\
Listening & 37 & 23 & 32 & 20 & 39 & 24.4 & 30 & 18.8 & 22 & 13.8 \\
Speaking & 30 & 18.7 & 32 & 20 & 34 & 21.3 & 37 & 23.1 & 27 & 16.9 \\
Grammar & 51 & 31.9 & 44 & 27.5 & 29 & 18.1 & 20 & 12.5 & 16 & 10 \\
Vocabulary & 51 & 31.8 & 42 & 26.3 & 31 & 19.4 & 19 & 11.9 & 17 & 10.6 \\
Pronunciation & 56 & 35 & 37 & 23.1 & 23 & 14.4 & 23 & 14.4 & 21 & 13.1 \\
\hline
\end{tabular}

Among the areas in which Turkish as a foreign language teachers generally want to develop themselves the most among the areas given in the questionnaire, were teaching Turkish for academic purposes (55\%), using technology in language teaching (53.7\%), developing evaluation instruments (52.6\%), new developments in foreign language teaching (52.5\%), teaching four skills together (45\%), various teaching techniques $(43.7 \%)$, use of games in foreign language teaching $(42.6 \%)$ and using drama in foreign language teaching (42\%). The reason why there is a variety in the needs the teachers feel to develop themselves professionally can be the fact that the teachers in this area completed their undergraduate education in different departments.

In order to provide a better understanding of what teachers of Turkish as a foreign language perceive as their professional development needs 15 teachers were asked to list the needs they have in the field. The analysis of this question led to the following findings.

In the interviews participant teachers also stated that, as this field does not have an undergraduate program, teachers working in this field have different educational backgrounds. Therefore, even if they feel the need to develop themselves in teaching speaking and writing skills, the institutions they work in do not provide opportunities for the teachers to develop themselves in these areas.

For instance, we do practices in our classrooms and then share with each other. In the speaking class a teacher does an activity tells the other teachers about it. Or in the writing class teachers who are good at developing materials share them with other teachers. I wish I had the opportunity to participate in a professional development activity about these issues.

Moreover, in the interviews participant teachers mentioned their need to develop themselves in the evaluation of speaking and writing skills as well. 
We have difficulties in evaluation of speaking and writing in terms of objectivity. For example in writing I mark a paper 20 and another friend of mine marks 15. It is the same for speaking as well. We don't have this problem in reading and listening. There has to be a rubric to evaluate these skills so as to achieve validity and reliability.

As for another need stated by 12 out of 15 participants is that teachers should be able to recognize the foreign language learning process to emphasize with their students, and be competent in one foreign language, when teaching Turkish to these students.

To make this job better, the foreign language must be at a good level. Most of the incoming students are at Al level, in order to communicate with them, you need to develop yourself, especially in English speaking skills.

Another need mentioned by 11 out of 15 of the Turkish as a foreign language teachers is to learn the culture of the students who constitute the target group because they are lecturing the students from different cultures while working in this area.

It could be a cultural education because a gesture or mimic of swearing in Africa can be a good thing for us. Something good in our culture can have a bad meaning in Kyrgyzstan. For this reason, we can all get training on this issue both students and teachers.

3.2. Professional development needs of Turkish as a foreign language teachers in terms of age, experience in the field, department and most recent education degree variables

In order to find answer to the second research question chi-square analysis was conducted with age, experience in the field, educational background and most recent education degree variables.

\subsubsection{Findings related to the comparison of professional development needs of teachers of Turkish as a foreign language in "teaching and evaluation" according to the age variable}

The professional development needs of the participant teachers were compared by using the chisquare test according to age variable. A significant difference was found among the views of the teachers on the professional development needs in teaching speaking according to age variable $(p=0.046)$. Participants in the age group 22-29 felt more need to develop themselves professionally in teaching speaking than the participants in age groups 30-39 and 40 and above. No statistically significant differences were found for other conditions $(p>0.05)$. Younger teachers felt more need in teaching productive skills.

According to the age variable, the professional development needs in evaluation were compared by using the chi square test. There was no significant difference between the opinions regarding the professional development needs in the evaluation field according to the age variable $(p>0.05)$.

\subsubsection{Findings related to the comparison of professional development needs of teachers of Turkish as a foreign} language "related to the field" according to the age variable

The frequency of professional development needs related to the field in terms of the age variable was compared by using the chi square test. There were differences according to age groups in the cases of "recognizing student differences, teacher training, peer observation and course book evaluation" for professional development needs related to the age variable. For the individuals in the age group of 40 and over for "recognizing student differences", the rate of not feeling need increased $(p=0.031)$. For the "teacher training" situation, participants did not feel a need as the age group increased $(p=0.002)$. The participants" need for "peer observation" was found to be higher in the age group 22-29, than the other groups ( $\mathrm{p}=0.023$ ). Likewise, there was a higher rate of need in "course book evaluation" in the 22-29 age group ( $\mathrm{p}=0.042)$ compared to the other groups. There was no statistically significant difference in other groups $(p>0.05)$. 
3.2.3. Findings related to the comparison of professional development needs of teachers of Turkish as a foreign language in "teaching" according to professional experience variable

According to professional experience variable, the professional development needs in teaching are compared with the chi-square test. According to the professional experience variable, there was a significant difference between the opinions about the professional development needs in teaching "grammar" $(p=0.002)$. Those with 1-5 years of professional experience had a higher educational need for grammar than other groups. No statistical difference was found in other variables $(p>0.05)$.

\subsubsection{Findings related to the comparison of professional development needs teachers of Turkish as a foreign language in "evaluation" according to the professional experience variable}

Professional development needs of the participants in evaluation according to the professional experience variable were compared by using the chi-square test. According to the professional experience variable, there was a significant difference among the professional development needs in terms of the evaluation of "grammar" $(p=0.016)$. When the proportions of these items were examined, it was seen that those with 1-5 years of professional experience needed more training in evaluation of grammar compared to other experience groups. There was no statistical difference in other groups $(p>0.05)$.

\subsubsection{Findings related to the comparison of professional development needs of teachers of Turkish as a foreign language "related to the field" according to professional experience variable}

According to professional experience variable, the frequency of professional development needs was compared by using the chi square test. According to the professional experience variable, statistical difference was obtained in the professional experience groups for the "European Language Portfolio" $(p=0.003)$. Those with a high level of professional experience did not feel the need for development in European Language Portfolio than other groups. However, there was a statistically significant difference according to professional experience in "time management" ( $p=0.023)$. For those with a high level of professional experience, they did not feel professional development need for time management. There was a difference in the items related to "teacher training" ( $p=0.027)$. Those who had more professional experience did not feel the need for professional development in teacher training. There was a statistically significant difference between the groups for "peer observation" $(p=0.013)$. Those with less professional experience (1-5 years) felt more need for peer observation than other groups. The need for "various teaching techniques" differed according to the professional experience groups $(p=0.015)$. In this group, those with 6-10 years of professional experience did not feel more need than other groups. There was a statistically significant difference in terms of "course book evaluation" $(p=0.009)$. In this group, participants with 6-10 years of professional experience did not feel much development need for "various teaching techniques" compared to other groups. Those with higher professional experience felt less need for development in "teaching in multicultural classes" $(p=0.001)$.

\subsubsection{Findings related to the comparison of professional development needs of teachers of Turkish as a foreign language in "teaching, evaluation and field" according to the department variable}

Comparisons were made between the departments that had the required observation numbers for the chi-square analysis. This number was achieved in Turkish Education and Turkish Language and Literature departments. There was no significant difference between the opinions regarding the professional development needs in the teaching, evaluation and the field according to the department variable $(p>0.05)$.

\subsubsection{Findings on the comparison of professional development needs of teachers of Turkish as a foreign} language in "teaching and evaluation" according to the education variable

According to the education variable, the professional development needs in teaching and evaluation were compared by using the chi square test. There was no significant difference between the opinions 
regarding the professional development needs in the teaching field according to the education variable $(p>0.05)$.

\subsubsection{Findings related to the comparison of professional development needs of teachers of Turkish as a foreign language "related to the field" according to the education variable}

The frequency of professional development needs was compared by using the Chi square test according to the education variable. According to the education variable there was a statistically significant difference in terms of "teaching of four skills" $(p=0.023)$. Those who completed their undergraduate degree needed a lot of training in this area. Statistical difference was obtained regarding the education level variable in "preparing course material" $(p=0,006)$. Participants who completed their undergraduate degree need a lot of training in this area. There was a difference in education level variable in terms of "time management" $(p=0.006)$. The degree of need for undergraduate participants in time management was higher than the other groups. There was a statistical difference in "teacher training" ( $p=0.035)$. Those with undergraduate degrees felt more need for teacher training than other groups. There was a statistically significant difference between the groups in "peer observation" $(p=0.044)$. The degree of need for peer observation for undergraduates was higher than other groups. Statistically significant difference was found in "course book evaluation" $(p=0.042)$. In this group, the degree of need for the "various teaching techniques" was higher for the participants with the undergraduate degree than the other groups. Participants with undergraduate degree felt more need for professional development in "Reflective Teaching" than other groups $(p=0.005)$.

\section{Discussion}

The present study sought to examine the professional development needs of Turkish as a foreign language teachers and to find out whether there was any difference among the professional development needs of teachers in terms of age, experience, latest graduation degree and education. An important finding of the study revealed that the skills that teachers felt the need for professional development are speaking and writing skills in both assessment and teaching. This finding confirms that of Kan, Sülüşoğlu and Demirel (2013) who also reported that most students had difficulty in developing speaking skills. Similarly, this finding is in line with that of İşcan, Yağmur Şahin, Kana, and Koçer (2013) who indicated that Turkish as a foreign language students perceived speaking skills as the second most difficult skill after listening skills. It can therefore be assumed that Turkish as a foreign language teachers are expected to feel more need to improve themselves in teaching and evaluation of these skills since they require language production.

Another finding of this study is that teachers need to improve themselves in the areas of Academic Turkish, use of technology in foreign language teaching, developing an evaluation instrument, new developments in foreign language teaching, teaching four skills together, various teaching techniques, use of games in foreign language teaching, and using drama in foreign language teaching. It seems that the teachers with different educational backgrounds in this area have also increased the diversity of the needs.

It was also found that the professional development needs of participating teachers differed according to age and professional experience and the latest educational degree. In the chi-square analysis according to the age variable, teachers feel the need for self-improvement more in the 22-29 age group than the age group of 40 and above in the field of teaching speaking skills. This finding is reasonable as speaking skill which is a productive skill require experience in teaching. There were differences according to age variable in "recognition of student diversity, teacher training, peer observation and textbook evaluation" cases. Participants who are in the age group of 40 and over have a higher rate of showing no need to be 
able to recognize student differences. For "teacher training", the older age group did not feel need for development in this area. In the international literature, the teachers' age is defined as a determinant of participation in professional development activities (Desimone, Smith, \& Ueno, 2006; Richter, Kunter, Klusmann, Lüdtke, \& Baumert, 2011). The TALIS (2013) study showed that the number of professional development activities teachers attended decrease with the increase in teacher age. This suggests that less experienced teachers participate in more professional development activities than experienced teachers.

In the Chi-square analysis conducted according to the variable of professional experience, it was seen that the teachers who had 1-5 years of experience felt the need for further development in the teaching and assessment of grammar. According to professional experience, Turkish as foreign language teachers with 1-5 years of experience felt more need to develop themselves in "European Language Portfolio, time management and teacher training, and peer observation" more than other groups. In the international literature, the age of the teacher is defined as a determinant of participation in professional development activities. Therefore, as age and experience increase, the need for professional development and the participation rate decrease.

There was no significant difference in the teaching and assessment needs according to the latest education level variable. Only the "teaching of four skills together, preparation of course material, time management, teacher training and peer observation" were different. Those who completed their undergraduate studies were found to have a need for more training in these areas. Alade and Odebode (2014) have shown that age, gender, educational background and years of teaching are not a significant influence on the benefits teachers have from their professional development activities.

\section{Conclusions}

With the purpose of revealing what the Turkish as foreign language teachers perceive as their professional development needs, a mixed method research was conducted. According to the results, the skills that teachers need to develop both in the assessment and the teaching are speaking and writing skills. Professional development needs of the teachers vary according to age, professional experience, the department they graduated from and the latest graduation degree. To sum up, a major suggestion that can be made regarding to the results of the study is that it is evident that the trainings given in different departments do not fully meet the needs of the teachers working in this area. Opening the department of "Teaching Turkish as a foreign language" in universities will eliminate this diversity and enable teachers who want to work in this area to feel more competent by receiving a training that is more comprehensive and meeting their needs. Moreover, as a result of the research, it was observed that the teachers working in this area did not receive regular training as pre-service and in-service training at the beginning and after the start of their profession. Pre-service and in-service trainings and ongoing developments to be determined on a regular basis and in line with the needs of teachers need to be supported for teachers working in this area. Continuity in trainings and more systematic training will increase the effectiveness and efficiency of trainings.

\section{References}

Alade, O., \& Odebode, O. (2014). An assessment of the impact of the teachers' professional development program under Lagos "Eko" Secondary Education Project in Lagos State. Journal of Education and Practice, 5, 1-8.

Altschuld, J. W., \& Kumar, D. D. (2010). Needs assessment: An overview. Thousand Oaks, CA: Sage. 
Arıkan, N. (2002). A teacher study group as an alternative method for professional development: Analysis of initial procedures in group formation, group dynamics, and teacher perceptions of and attitudes to the teacher study group. Yayımlanmamış Yüksek Lisans Tezi. Ankara: Bilkent Üniversitesi.

Bayraktaroğlu, A., \& Bayraktaroğlu, S. (1992). Colloquial Turkish. London: Routledge.

Borg, S. (2015). Overview - Beyond the workshop: CPD for English language teachers. In S. Borg (Ed.), Professional development for English language teachers: Perspectives from higher education in Turkey (pp. 5-12). Ankara: British Council.

Brown, J. D. (1995). The elements of language curriculum: A systematic approach to program development. Boston, MA: Heinle and Heinle.

Creswell, J. W. (2012a). Educational research: Planning, conducting, and evaluating quantitative and qualitative research. (4th ed.) Boston, MA: Pearson.

Creswell, J. W. (2012b). Qualitative inquiry \& research design: Choosing among five approaches (4th ed.). Thousand Oaks, CA: Sage.

Çınkır, G. (2017). Professional development of secondary EFL teachers: Lessons from Turkey [Ortaokulda çalışan İngilizce öğretmenlerinin mesleki gelişimi: Türkiye örneği]. Yayımlanmamış Yüksek Lisans Tezi. İstanbul: Çağ Üniversitesi.

Desimone, L. M., Porter, A. C., Garet, M. S., Yoon. K. S., \& Birman, B. F. (2002). Effects of professional development on teachers' instruction: Results from a three-year longitudinal study. Educational evaluation and policy analysis, 24(2), 81-112.

Desimone, L. M., Smith, T., and Ueno, K. (2006). Are teachers who need sustained, content-focused professional development getting it? An administrator's dilemma. Educational Administration Quarterly, 42, 179-215.

Ekşi, G. (2010). An assessment of the professional development needs of English language instructors working at a state university. Yayımlanmamış Yüksek Lisans Tezi. Ankara: ODTÜ.

Ganser, T. (2000). An ambitious vision of professional development for teachers. NASSP Bulletin, 84(618), 6-12.

Glatthorn, A. (1995). Teacher development. In L. W. Anderson (Ed.), International ecyclopedia of teaching and teacher education ( $2^{\text {nd }}$ ed.) (pp. 41-46). Oxford, UK: Pergamon.

Göçer, A. (2009). Türkçe eğitiminde öğrencilerin söz varlığını geliştirme etkinlikleri ve sözlük kullanımı. [Activities in improving vocabulary knowledge of students in Turkish education and using dictionary] Electronic Turkish Studies, 4(4), 1025-1055.

Göçer, A., ve Moğul, S. (2011). Türkçenin yabancı dil olarak öğretimi ile ilgili çalışmalara genel bir bakış [A general look at the studies related to teaching Turkish as a foreign language]. Electronic Turkish Studies, 6(3), 797-810.

Guskey, T. R., (2000). Evaluating professional development. Thousand Oaks, CA: Corwin Press.

Gültekin, İ. (2007). The analysis of the perceptions of English language instructors at TOBB University of economics and technology regarding in-set content. Yayımlanmamış Yüksek Lisans Tezi. Ankara: ODTÜ.

İşcan, A., Yağmur Şahin, E., Kana, F., ve Koçer, Ö. (2013). Yabanc1 dil olarak Türkçe öğrenen öğrencilerin ihtiyaç algıları: betimsel bir durum çalışması. [Perceptions of students who learn 
Turkish as a foreign language: a descriptive case study] International Journal of Social Science, 6(4), 1185-1198

Kaila, H. L. (2005). Human resource management. New Delphi, India: Kalpaz Publication.

Kan, M. O., Sülüşoğlu, B., ve Demirel, Ö. (2013). Yabancı dil olarak Türkçe öğretimi programı ile ilgili okutman ve öğrenci görüşlerinin değerlendirilmesi [Assessment of instructors and students' opinions about program for teaching Turkish as a foreign language]. Mustafa Kemal Üniversitesi Sosyal Bilimler Enstitüsü Dergisi, 10(24), 29-42.

Karaaslan, A. D. (2003). Teachers' perceptions of self-initiated professional development: a case study on Başkent University English language teachers. Yayımlanmamış Yüksek lisans Tezi. Ankara: ODTÜ.

King, M. B., and Newmann, F. M. (2000). Will teacher learning advance school goals? Phi Delta Kappan, 81(8), 576-580.

Koçoğlu, Z. B. (2006). The role of portfolios in EFL student teachers' professional development: a case study [Portfolyoların ingilizce eğitimi anabilim dalı ögretmen adaylarının mesleki gelişimlerindeki rolü: bir durum çalışması ]. Yayımlanmamış Yüksek Lisans Tezi. İstanbul: Boğaziçi Üniversitesi.

Korkmaz, T. (2015). In-service ELT teachers' first year with reference to mentor teachers and professional development [Görevdeki İngilizce ögretmenlerinin meslekteki ilk yıllarının rehber ögretmen ve mesleki gelişim açılarından değerlendirilmesi]. Yayımlanmamış Yüksek Lisans Tezi. Ankara: Ufuk Üniversitesi.

Korkmazgil, S. (2015). An investigation into Turkish English language teachers' perceived professional development needs, practices and challenges. Yayımlanmamış Doktora Tezi. Ankara: ODTÜ.

Lieberman, J. and Wilkins, E. (2006). The professional development pathways model: from policy to practice. Kappa Delta Pi Record, 42 (3), 124-128.

McLaughlin. M. W., and Talbert, J. E. (2006). Building school-based teacher learning communities: professional strategies to improve student achievement. New York: Teacher College Press.

Muyan, E. (2013). A case study on ELT teachers' perceptions towards professional development acivities [İngilizce ögretmenlerinin mesleki gelişim etkinliklerine yönelik tutumlart ile ilgili durum çalışması]. Yayımlanmamış Yüksek Lisans Tezi. İstanbul: Çağ Üniversitesi.

Nunan, D. (1998). Syllabus design. Oxford: Oxford University Press.

Richards, J. C., \& Farrell, T.S.C. (2005). Professional development for language teachers: Strategies for teacher learning. Cambridge: Cambridge University Press.

Richards, J. C., \& Schmidt, R. (2010). Longman dictionary of language teaching and applied linguistics (4th ed.). Harlow, CM: Pearson.

Richter, D., Kunter, M., Klusmann, U., Lüdtke, O., \& Baumert, J. (2011). Professional development across the teaching career: Teachers' take-up of formal and informal learning opportunities. Teaching and Teacher Education, 27, 116-126.

(TALIS) Teaching and learning international survey. (2013). Teaching and learning international survey: user's guide to 2013 U.S. data files and database. Retrieved on June 6, 2017 from http://nces.ed.gov/ pubs2016/2016063_userguide.pdf. 
Wyatt, M. (2016). Engaging language teachers in research: achieving psychological ad educational benefits. In K. Dikilitaş, M. Wyatt, J. Hanks, and D. Bullock, (Eds.), Teachers Engaging in Research. (pp. 3-18), Kent: IATEFL ReSIG.

Yağc1, H. (2014). Tracking changes and progress in EFL teachers' classroom practices through professional development: the case of Gaziantep. [İngilizce ögretmenlerinin mesleki gelişim aracılı̆̆ıyla sınıf uygulamalarındaki değişim ve ilerlemelerinin izlenilmesi: Gaziantep ili örneği]. Yayımlanmamış Yüksek Lisans Tezi. Ankara: Hacettepe Üniversitesi.

Yıldırım, A. ve Şimşek, H. (2013). Sosyal bilimlerde nitel araştırma yöntemleri (9th ed.) [Qualitative research methods in social sciences]. Ankara: Seçkin.

\title{
Yabancı dil olarak Türkçe öğretmenlerinin algılanan mesleki gelişim ihtiyaçlarının değerlendirmesi
}

\begin{abstract}
$\ddot{O} \mathbf{z}$
$\mathrm{Bu}$ araştırmanın amacı, Türkiye'de yabancı dil olarak Türkçe öğretmenlerinin mesleki gelişim ihtiyaçlarını açıklamak ve bu alanda farklı eğitim alarak çalışmaya başlamış öğretmenlerin mesleki gelişim ihtiyaçları arasında farklılık olup olmadığını araştırmaktır. Bu amaçla ilk olarak bu alanda çalışan 160 öğretmenin mesleki gelişim ihtiyaçları anket aracıllğıyla belirlenmiştir. Sonra Ankara'daki Türkçe öğretim merkezlerinden rastgele seçilen 15 öğretmenle odak grup görüşmeleri yapılmıştır. Çalışmanın evrenini Türkiye'de farklı üniversitelerdeki TÖMER'lerde ve enstitülerde görev yapan öğretmenler oluşturmaktadır. Araştırma yöntemi olarak sıralı açıklayıcı karma desen kullanılmıştır. Verilerin analizinde betimsel ve sayısal istatistik analizlerinden ve görüşmelerde ise içerik analizinden faydalanılmıştır. Araştırmanın sonuçlarına göre katılımcı öğretmenlerin, hem ölçmedeğerlendirme hem de öğretim alanında mesleki gelişim ihtiyacı hissettikleri beceriler konuşma ve yazma becerileri olmuştur. Katılımcı öğretmenlerin mesleki gelişim ihtiyaçları yaş ve mesleki tecrübe, mezun olunan bölüm ve en son alınan dereceye göre farklılık gösterdiği görülmüştür. Öğretmenlerin ihtiyaçlarının mezun oldukları bölümlere göre farklıllk gösterdiği gözlemlenmiştir.
\end{abstract}

Anahtar sözcükler: Mesleki gelişim; yabancı dil olarak Türkçe öğretimi; ihtiyaç analizi

\section{AUTHOR BIODATA}

Nihan Aylin Ünlü is an instructor at Hacettepe University. She received MA degrees from Hacettepe University and Bilkent University. She completed her PhD in Teaching Turkish as a Foreign Language. Her research interests are teaching Turkish as a foreign language, teaching English as a foreign language.

Hüseyin Öz was an associate professor of applied linguistics and English language teaching at Hacettepe University. He received his MA degree from Middle East Technical University and his PhD degree in Linguistics from Hacettepe University, where he taught undergraduate and graduate courses in language teaching methods and approaches, research methods, applied linguistics, second language acquisition research, language assessment, and technology enhanced language learning (TELL). He published widely in various refereed international journals and presented papers in national and international conferences. He also served on the editorial boards of 
632 Nihan Aylin Ünlü, Hüseyin ÖZ / Journal of Language and Linguistic Studies, 15(2) (2019) 618-632

several national and international publications and was the associate and managing editor of Eurasian Journal of Applied Linguistics. 